\title{
ANALISIS PENGELOLAAN REPOSITORI INSTITUSI PADA LEMBAGA PENENELITIAN DENGAN STATUS PUSAT UNGGULAN IPTEK (PUI)
}

\author{
Tupan*, Noorika Retno Widuri*, Rochani Nani Rahayu*, \\ Mohamad Djaenudin*, Cahyo Trianggono*
}

*Pusat Data dan Dokumentasi Ilmiah, Lembaga Ilmu Pengetahuan Indonesia (LIPI)

Email: tupan712190@yahoo.com

(Submitted: 07-01-2020, Revised: 02-06-2020, Accepted: 04-06-2020)

DOI: $10.24252 /$ kah.v8i1a5

\begin{abstract}
ABSTRAK: Artikel ini mengkaji tentang pengelolaan repositori di Lembaga Penelitian dengan Status PUI. Data diperolah melalui wawancara dan kuesioner. Wawancara dilakukan terhadap pengelola repositori yang mempunyai kapasitas dan kemampuan dalam mengelola repositori. Sedangkan kuesioner disebarkan melalui email Lembaga Penelitian dengan status PUI. Hasil penelitian menunjukkan bahwa lembaga penelitian dengan status PUI sebagian besar sudah memiliki repositori. Repositori berfungsi tempat penyimpanan data dan karya ilmiah untuk jangka panjang dalam bentuk digital. Repositori memudahkan orang untuk menelusur atau merujuk data dan karya penelitian lain. Ketersediaan repositori institusi dapat memfasilitasi antar disiplin ilmu. Faktor yang mendorong penggunaan repositori adalah tampilan web repositori menarik, dilengkapi dengan fasilitas penyimpanan dan pencarian data serta mudah diakses. Sedangkan faktor yang menghambat penggunaan repositori adalah lembaga penelitian belum mewajibkan peneliti untuk menyimpan data penelitian dalam repositori. Faktor lain yang menghambat penggunaan repositori adalah perilaku peneliti yang tidak melakukan backup data. Untuk meningkatkan pengelolaan repositori di lembaga penelitian diperlukan kebijakan yang mewajibakan peneliti menyimpan datanya di repositori serta memberikan sanksi kepada peneliti yang tidak menyimpan datanya di repositori. Diperlukan sosialisasi yang dilakukan secara berkala agar para peneliti sadar akan pentingnya data dan karya hasil penelitian.
\end{abstract}

Kata kunci: Repositori institusi; pengelolaan data penelitian; lembaga penelitian

\section{ANALYSIS OF INSTITUTIONAL REPOSITORY MANAGEMENT IN RESEARCH INSTITUTIONS WITH STATUS AS CENTER OF EXCELLENCE SCIENCE AND TECHNOLOGY (PUI)}

ABSTRACT: The article examines the management of repositories at Research Institutions with PUI status. The data were obtained through interviews and questionnaires. The interviews were conducted with repository staff who had the capacity and ability to manage repositories. While the questionnaire was distributed via e-mail to each Research Institute. The results showed that most research institutions with PUI status have already its repository. Repository functions for long-term storage of data and scientific work in digital form. Repositories make it easy for people to search or refer research works. The availability of institutional repositories can facilitate interdisciplinary fields. The factors that encourage the use of repositories were attractive web appearance, equipped with data storage and search facilities, and easily accessed. While the factors that inhibit the use of repositories were research institutions do not require researchers to store their works, and the behavior of researchers who did not backup their data. To improve the management of repositories in research institutes, a policy is required that requires researchers to store their data in the repository and impose sanctions. The periodic socialization was needed so that researchers are aware of the importance of data and research results.

Keywords: Institutional repository; research data management; research organization 


\section{PENDAHULUAN}

Repositori institusi menurut Kumar (2009) adalah basis data material atau bahan-bahan ilmiah berbasis web, yang bersifat kumulatif, terbuka serta terinteroperabilitas bisa menggunakan perangkat lunak. Repositori institusi meliputi kegiatan mengumpulkan, menyimpan, menyebarkan sumber daya digital sekaligus melindungi bahan digital untuk penggunaan jangka panjang. Esensi dari repositori institusi adalah untuk membuat penelitian dan pengembangan publikasi dapat bebas tersedia di internet.

Di perguruan tinggi, repositori institusi menjadi umum, karena institusi menghadapi kendala seperti adanya kenaikan biaya langganan informasi, sehingga mengalami keterbatasan akses terhadap perubahan teknologi dengan cepat, informasi yang diperlukan, serta terjadinya sisi anggaran tetap, dan perpustakaan tetap dituntut untuk melaksanakan layanan prima dengan koleksi yang berkualitas (Kumar Roy, 2012).

Koleksi repositori institusi dapat berupa apapun dalam bentuk materi digital yang dimiliki, dikendalikan dan disebarluaskan oleh berbagai institusi dengan tidak mengabaikan tujuan awal dari organisasi. Repositori ada dalam berbagai bentuk dan melayani berbagai keperluan dari setiap fungsi lembaga induk suatu organisasi. Arsip digital missal karya intelektual yang dihasilkan fakultas, staf peneliti, mahasiswa, seharusnya dapat diakses oleh pengguna tanpa hambatan yang berarti (Kumar, 2009 ). Saat ini, lembaga penelitian di Indonesia tersebar di berbagai kementerian di Indonesia. Sebagai contoh, Kementerian Pertanian memiliki berbagai pusat penelitian di antaranya, Balai Penelitian Lingkungan Pertanian, Badan Litbang Pertanian. Kementerian Kehutanan memiliki Balai Penelitian Tanaman Hutan, Balai Penelitian Tanaman Industri, Balai Penelitian Tanaman Rempah dan Obat, dan lain-lain. Kementerian Perindustrian memiliki Balai Penelitian Tanaman Industri dan Penyegar, Balai Pengembangan dan Pengembangan Industri, dan lain-lain. Tercatat hingga saat ini lebih dari 100 lembaga penelitan. Pemerintah memberikan Penghargaan ke 101 Lembaga Penelitian termasuk Lembaga Penelitian Sosial dan Perusahaan (Ristekdikti; 2018).

Sebagai bench mark, Malaysia, dikutip dari Directory of Institutional Repositories in Malaysia; diakses 26 Februari 2019, bahwa diketahui repositori institusi di Malaysia berjumlah 26, yang berasal dari perguruan tinggi. Menurut Asmad, C. C. (2018) saat ini di Indonesia telah terdaftar sebanyak 70 repositori institusi perguruan tinggi yang terdata di Open DOAR. Bagi perguruan tinggi, repositori institusi adalah layanan yang diberikan kepada civitas akademika dalam rangka mengatur, mengorganisasikan, mengelola, dan menyebarkan karya ilmiah berbentuk elektronik yang berasal dari civitas akademika itu sendiri. Melalui itu, karya intelektual yang telah dihasilkan dapat dikelola dengan baik, dilestarikan agar dapat digunakan dalam jangka waktu yang panjang, mendukung kegiatan administrasi perguruan tinggi, dan mudah diakses dan didistribusikan kepada dunia (Asmad, C.C.; 2018).

Konten repositori institusi perguruan tinggi di Indonesia biasanya berupa tugas akhir seperti skripsi, tesis, disertasi, buku teks, buku modul, laporan penelitian dan proyek suatu komunitas, laporan layanan, laporan praktikum atau laporan praktek kerja lapangan, makalah lokakarya/seminar, hasil paten, hasil penghargaan kompetisi pelajar untuk rangking satu hingga ketiga di perguruan tinggi/regional/nasional/dan tingkat internasional (Farida et al. 2015; dalam Asmad, C.C ; 2018). Menurut Kumar, N. Ashok (2009) konten repositori institusi dapat berupa, preprint dari artikel atau laporan penelitian yang dikirimkan ke penerbit, naskah artikel jurnal yang diterima oleh penerbit, artikel hasil revisi beserta komentar dari rivewer, makalah konferensi, bahan ajar, proyek mahasiswa, tesis dan disertasi, dataset dari hasil penelitian, software computer, pekerjaan seni, foto dan rekaman video.

Perkembangan di dalam informasi dan komunikasi serta teknologi web telah merubah cara informasi diproduksi, diakuisisi dan disebarluaskan. Teknologi tersebut berhasil secara revolusioner mengubah sistem layanan perpustakaan konvensional dan menggantikannya dengan layanan koleksi informasi digital (Jain, S.J dan S. Anurag ; 2018). Repositori institusi 
menganut sistem akses terbuka dengan cara mengarsipkan sendiri (self-archiving) salinan dari arikel yang sudah dipublikasikan di dalam jurnal dan dapat diakses secara cuma-cuma. Oleh karena itu, saat ini repositori institusi menjadi salah satu komponen yang penting di dalam lembaga penelitian. Repositori adalah jawaban terhadap adanya keterbatasan akses kepada ilmu pengetahuan dalam keilmuan dan berbagai jurnal ilmiah yang dipaksakan oleh penerbit komersial melalui biaya berlangganan, lisensi biaya atau biaya bayar per tayang (Gideon ;2008; dalam Abrizah, A; et al ; 2010).

Pada tahap awal, repositori institusi terutama yang berada di pendidikan tinggi merupakan kewajiban yang diharuskan bagi peneliti untuk menyimpan secara mandiri karena para peneliti sudah mendapatkan intensif penelitian dari institusi tempat mereka bekerja. Hal tersebut terutama ditujukan untuk menyebarkan pekerjaan mereka seluas mungkin (meningkatkan dampak) dan untuk berkontribusi pada pengembangan pengetahuan dalam bidang mereka (Chan: 2004, dalam Abrizah, A; et al; 2010).

Adapun tujuan diadakannya repositori institusi menurut Kumar (2009) adalah untuk:

1. Mewujudkan visibilitas global akan hasil karya (produk/output) institusi.

2. Mengumpulkan konten dalam satu lokasi.

3. Menyediakan akses terbuka kepada hasil karya produk/output) institusi.

4. Menyimpan dan melestarikan asset digital, termasuk unpubhlised atau karya lain yang mudah hilang seperti literatur kelabu (laporan teknis, tesis, dan lain-lain).

Kajian pengelolaan repositori pernah dilakukan oleh Rifqi (2018) yang menggambarkan bagaimana UPT Perpustakaan Politeknik Negeri Malang mengimplementasikan sistem repositori sebagai wadah informasi konten digital. Ulum (2015) melakukan kajian yang mengevaluasi website repositori institusi Universitas Surabaya. Kajian ini menggunakan studi evaluasi terhadap website repositori institusi yang menggunakan Eprints. Kriteria evaluasi yang digunakan berdasarkan pada disertasi yang ditulis oleh Sunita A. Barve dengan judul "An Evaluation of Open Source Software for Building Digital Libraries". Yaniasih (2015) mengkaji repositori institusi Lembaga Penelitian dan menyusun desain konseptual yang dapat direkomendasikan bagi pengembangan repositori institusi di Lembaga Ilmu Pengetahuan Indonesia (LIPI). Penelitian bertujuan untuk menganalisis swaarsip peneliti, fitur web, regulasi, dan kebijakan pengelolaan repositori institusi Lembaga Penelitian serta membuat desain konseptual kebijakan dan web repositori institusi yang berkualitas global dan mendukung swaarsip.

Hasil penelitian Kumar, (2009) tentang repositori insitusi di India menyatakan bahwa di India terdapat sebanyak 31 repositori institusi, yang kepemilikannya meliputi 58\% merupakan repositori lembaga penelitian, 29\% adalah repositori perguruan tinggi (akademik) dan 13\% adalah merupakan repositori korporat. Adapun jenis software yang digunakan adalah Dspace sebanyak 80,64\%, kemudian GNU Eprints berjumlah 16,13\% dan Greenstone hanya $1 \%$.

Penelitian yang dilakukan oleh Asmad, C. C. (2018) terhadap repositori istitusi perguruan tinggi di Indonesia menunjukkan bahwa jenis-jenis koleksi repositori meliputi tesis dan disertasi, artikel jurnal, makalah konferensi, buku, bagian dari buku, laporan yang tidak didokumentasikan, bahan ajar, refernsi bibliografi, multi media dan audio visual, data set, dan paten. 


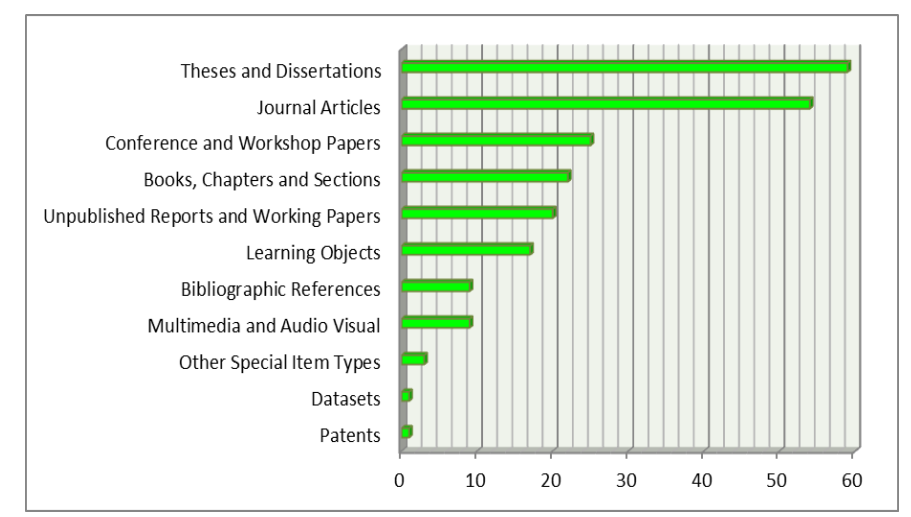

Grafik1. jumlah content OAIR di Perguruan Tinggi Indonesia (Sumber: Asmad, C. C.; 2018)

Adapun untuk perangkat lunak, maka repositori institusi perguruan tinggi di Indonesia lebih banyak menggunakan EPrint (77\%), DSpace (13\%), dan perangkat lunak lainnya sebesar $1 \%$. Beberapa penelitian tentang repositori yang ada di Indonesia baru menyentuh ranah akademik dalam hal ini perguruan tinggi, akan tetapi untuk repositori institusi di kalangan lembaga penelitian belum banyak dilakukan, oleh karena itu penelitian ini akan mengeksplor repositori institusi di kalangan lembaga penelitian di Indonesia. Adapun untuk Lembaga Penelitian terdapat 101 lembaga yang mendapatkan pengahargaan dari Kemenristekdikti. Dari 101 lembaga terdapat 35 lembaga mendapat status sebagai Pusat Unggulan Ipek (PUI). Berdasarkan pada latar belakang di atas terdapat beberapa rumusan masalah antara lain:

1. Bagaimana ketersediaan repositori untuk penyimpanan hasil penelitian di Lembaga penelitian dengan status PUI?

2. Bagaimana proses pengeloaan repositori di Lembaga Penelitian dengan Status PUI?

3. Apa saja jenis repositori yang digunakan oleh Lembaga Penelitian dengan status PUI?

4. Apa manfaat kebijakan pengelolaan repositori yang diterapkan di Lembaga penelitian dengan status PUI?

5. Apa saja faktor pendorong dan penghambat penggunaan repositori di lembaga penelitian dengan status PUI?

6. Bagaimana solusi yang diambil di dalam penyelesaian kendala/hambatan dalam penggunaan repositori di Lembaga penelitian dengan status PUI?

Berdasarkan latar belakang dan permasalahan di atas dilakukan penelitian Analisis Pengelolaan Repositori Institusi pada Lembaga Penenelitian dengan Status Pusat Unggulan Iptek (PUI) yang bertujuan untuk mengetahui ketersediaan repositori, pengelolaan dan jenis-jenis repositori, manfaat pengelolaan repositori, faktor pendorong dan penghambat penggunaan repositori dan memberikan solusi dalam menyelesaikan kendala/hambatan dalam penggunaan repositori di lembaga penelitian.

Hasil penelitian diharapkan dapat digunakan sebagai masukan kepada pimpinan lembaga penelitian khususnya lembaga penelitian dengan status PUI dalam mengembangkan repositori Ilmiah. Adanya repositori ilmiah yang dikembangkan oleh lembaga penelitian dan pengembangan dengan status PUI dapat diikuti pengembangannya oleh lembaga penelitian lain, sehingga karya ilmiah yang dihasilkan dapat tersimpan dan ditelusur kembali untuk pengembangan ilmu pengetahuan di masa yang akan datang.

\section{METODOLOGI PENELITIAN}

Penelitian dilakukan terhadap pengelolaan repositori ilmiah pada lembaga penelitian dengan status PUI dari Kemenristekdikti. Pengkajian ini bersifat deskriptif yang bertujuan untuk menjelaskan suatu keadaan atau fenomena yang terjadi. Sebagaimana yang dikemukakan oleh 
Sukmadinata (2006) dan Sugiyono (2011), metode penelitian deskriptif adalah sebuah metode yang digunakan untuk mendeskripsikan dan menginterpretasikan sesuatu fenomena, misalnya kondisi atau Hubungan yang ada, pendapat yang berkembang, dengan menggunakan prosedur ilmiah untuk menjawab masalah secara actual. Populasi penelitian adalah ketersediaan repositori institusi lembaga penelitian di Indonesia yang berstatus PUI dari Kemenristekdikti.

Pengumpulan data dilakukan melalui wawancara dan kuesioner terhadap pengelola repositori institusi di Lembaga Penelitian dengan status PUI dari Kemenristekdikti. Wawancara dilakukan terhadap pengelola repositori yang mempunyai kapasitas dan kemampuan dalam mengelola repositri di Lembaga Penelitian Penelitian dengan status PUI dari Kemenristekdikti. Sedangkan kuesioner disebarkan melalui email terhadap Lembaga Penelitian dengan status PUI dari Kemenristekdikti. Teknik analisis data yang digunakan adalah statistic deskriptif. Statistik deskriptif yaitu statistik yang digunakan untuk menganalisis data dengan cara mendeskripsikan atau menggambarkan data yang telah terkumpul sebagaimana adanya tanpa bermaksud membuat kesimpulan yang berlaku umum atau generalisasi (Sugiyono, 2013).

\section{HASIL DAN PEMBAHASAN}

Responden dalam penelitian ini sebanyak 27 orang dengan rincian 19 orang memberikan data melaui kuesioner dan 8 orang melalui wawancara secara langsung. Responden adalah pengelola repositori yang representatif dan layak untuk dijadikan responden dalam memberikan informasi mengenai identitas diri. Berikut karakteristik responden secara rinci.

Tabel 1. Responden Berdasarkan Jenis Kelamin

\begin{tabular}{cccc}
\hline No & Jenis Kelamin & Jumlah & Persentase \\
\hline 1 & Laki-laki & 12 & $63 \%$ \\
2 & Perempuan & 7 & $37 \%$ \\
\hline
\end{tabular}

Tabel 2. Responden Berdasarkan Usia

\begin{tabular}{cccc}
\hline No & Usia & Jumlah & Persentase \\
\hline 1 & $21-30$ & 0 & 0 \\
2 & $31-40$ & 7 & 36,8 \\
3 & $41-50$ & 3 & 15,8 \\
4 & $51-60$ & 7 & 36,8 \\
5 & $>60$ & 2 & 10,5 \\
\hline
\end{tabular}

Tabel 3. Responden Berdasarkan Tingkat Pendidikan

\begin{tabular}{cccc}
\hline No & Pendidikan & Jumlah & Persentase \\
\hline 1 & S1 & 5 & 26,3 \\
2 & S2 & 5 & 26,3 \\
3 & S3 & 9 & 47,4 \\
\hline
\end{tabular}

Berikut ini akan ditampilkan jawaban-jawaban responden, baik dalam kuesioner maupun interwiew.

Tabel 4. Kriteria Jawaban Responden Terkait Ketersediaan Repositori

\begin{tabular}{cccc}
\hline No & Katagori Jawaban & Frekuensi & Persentase \\
\hline 1 & Sangat Setuju & 4 & 21,1 \\
2 & Setuju & 11 & 57,9 \\
3 & Kurang setuju & 3 & 15,8 \\
\hline
\end{tabular}




\begin{tabular}{cccc}
\hline \hline 4 & Tidak Setuju & 1 & 5,3 \\
5 & Sangat tidak setuju & 0 & 0 \\
6 & Jumlah & 19 & 100 \\
\hline
\end{tabular}

Dari tabel 4. di atas menggambarkan bahwa lembaga yang sudah memiliki repositori sebesar 79\% atau sekitar 28 lembaga dari sekitar 35 lembaga. Hal ini didukung dari hasil wawancara kepada 10 responden pengelola repositori yang mengatakan bahwa lembaga penelitian dengan status pusat unggulan iptek sebagian besar sudah memiliki repositori. Berdasarkan hasil survei melalui kuesioner dan wawancara menunjukan bahwa jenis dokumen pada repositori yang dimiliki oleh lembaga penelitian adalah dalam bentuk karya ilmiah seperti jurnal, buku dan laporan penelitian. Sedangkan untuk repositori data primer sebagian besar lembaga penelitian belum melakukan. Alasan semua lembaga penelitian sudah memiliki dan mengembangkan repositori adalah karena adanya kebutuhan untuk menyimpan data dan karya yang mudah diakses. Hal tersebut sejalan dengan pendapat Yakel et al dalam Prayesti et al (2017) bahwa repositori merupakan teknologi yang mampu menyediakan fitur sebagai tolok ukur sebuah institusi/organisasi dalam mengukur produktivitas karya ilmiah yang dihasilkan. Dalam pengembangannya repositori memerlukan sistem akes terbuka (open access) dalam pengaksesannya. Manfaat reposotri adalah berbagi pengetahuan antara peneliti suatu lembaga dengan lembaga lain, antara peneliti dengan masyarakat, serta meningkatkan investasi di bidang informasi dan sistem manajemen konten, serta memberikan keleluasaan akses karya ilmiah.

Tabel 5. Kriteria Jawaban Respoden Terkait Tujuan Mengelola Repositori untuk Menyimpan Karya Ilmiah

\begin{tabular}{cccc}
\hline No & Katagori Jawaban & Frekuensi & Persentase \\
\hline 1 & Sangat setuju & 4 & 21,15 \\
2 & Setuju & 12 & 63,2 \\
3 & Kurang Setuju & 2 & 10,5 \\
4 & Tidak Setuju & 1 & 5,3 \\
5 & Sangat tidak Setuju & 0 & 0 \\
6 & Jumlah & 19 & 100 \\
\hline
\end{tabular}

Tabel 5. di atas menggambarkan bahwa 84\% responden mengatakan bahwa tujuan pengelolaan repositori adalah untuk menyimpan karya ilmiah. Pendapat yang sama juga diperoleh dari hasil wawancara dengan pengelola repositori Balai Besar Riset Pengolahan Produk dan Bioteknologi Kelautan dan Perikanan, Kementerian Kelautaan dan Perikanan yang mengatakan bahwa secara internal BBRP2KP sudah mengembangkan cloud server untuk menyimpan hasil penelitian dengan membuat database riset degan kapasitas 6 Tera dan setiap peneliti diberi akses untuk menyimpan data penelitian. Hal tersebut diperkuat dengan pendapat Zulaikha et al (2017) bahwa repositori merupakan media online yang bertujuan untuk menyimpan, melestarikan, dan menyebarluaskan produk intelektual lembaga dalam bentuk digital.

Tabel 6. Kriteria Jawaban Responden Terkait Ide untuk Mengembangkan Repositori karena Adanya Kebutuhan untuk Menyimpan Data dan Karya

\begin{tabular}{clcc}
\hline No & Katagori Jawaban & Frekuensi & Persentase \\
\hline 1 & Sangat setuju & 9 & 47,4 \\
2 & Setuju & 10 & 52,6 \\
3 & Kurang Setuju & 0 & 0 \\
4 & Tidak Setuju & 0 & 0 \\
5 & Sangat tidak Setuju & 0 & 0 \\
\hline
\end{tabular}




6 Jumlah 1900

Tabel 6. di atas menyimpulkan bahwa responden seratus persen setuju bahwa ide awal untuk mengembagkan repositori adalah adanya kebutuhan untuk menyimpan data dan karya yang mudah diakses. Hal tersebut juga didukung dari hasil wawancara beberapa responden yang mengatakan bahwa ide untuk mengembangkan repositori adalah berawal dari kebutuhan untuk mengumpulkan data hasil penelitian di satu tempat sehingga mudah untuk diakses. Responden lainnya mengatakan bahwa ide repositori itu muncul karena repositori merupakan output dari kegiatan PUI. Hal tersebut sesuai dengan hasil penelitian Prayesti et al. (2017) bahwa repositori dapat menyediakan tempat untuk menyimpan data yang tidak dapat dipublikasikan melalui jurnal.

Tabel 7. Kriteria Jawaban Responden Terkait Tujuan Pengelolaan Repositori untuk Menyimpan Hasil Penelitian dalam Satu Tempat

\begin{tabular}{cccc}
\hline No & Katagori Jawaban & Frekuensi & Persentase \\
\hline 1 & Sangat setuju & 11 & 57,9 \\
2 & Setuju & 8 & 42,1 \\
3 & Kurang Setuju & 0 & 0 \\
4 & Tidak Setuju & 0 & 0 \\
5 & Sangat tidak Setuju & 0 & 0 \\
6 & Jumlah & 19 & 100 \\
\hline
\end{tabular}

Tabel 7. di atas menyimpulkan bahwa responden seratus persen setuju bahwa pengelolaan repositori adalah untuk menyimpan hasil penelitian dalam satu tempat. Hal tersebut dibuktikan dengan jawaban responden yang mengatakan sangat setuju 57,9\% dan setuju 42,1\%. Hal tersebut juga didukung dari hasil wawancara yang mengatakan bahwa responden semua sepakat bahwa repositori memenuhi tujuan dalam rangka menyimpan data dalam satu tempat.

Tabel 8. Kriteria Jawaban Responden Terkait Pencapaian Pengelolaan Sistem Repositori di Lembaga Penelitian

\begin{tabular}{cccc}
\hline No & Katagori Jawaban & Frekuensi & Persentase \\
\hline 1 & Sangat setuju & 0 & 0 \\
2 & Setuju & 12 & 63,2 \\
3 & Kurang Setuju & 5 & 26,3 \\
4 & Tidak Setuju & 2 & 10,5 \\
5 & Sangat tidak Setuju & 0 & 0 \\
6 & Jumlah & 19 & 100 \\
\hline
\end{tabular}

Tabel 8. di atas menyimpulkan bahwa pengembangan pengelolaan repostori telah tercapai. Hal tersebut juga didukung dari hasil wawancara kepada pengelola repositori yang mengatakan bahwa pengembangan pengelolaan repositori telah tercapai walaupun masih banyak kekurangannya. Pendapat responden tentang pentingnya pengelolaan repositori didukung oleh pendapat Ernaningsih (2017) yang mengatakan bahwa repositori institusi banyak memberikan keuntungan terhadap lembaga, ilmu pengetahuan, dan peneliti maupun akademisi. Repositori institusi dapat meningkatkan posisi dan prestis lembaga karena dapat menjadi media promosi untuk menarik pendanaan riset, peneliti potensial, dan mahasiswa yang berkualitas untuk masuk ke lembaga tersebut. Adapun bagi ilmu pengetahuan, repositori dapat menjadi sarana preservasi dokumen melalui digitalisasi sekaligus dapat meningkatkan komunikasi ilmiah yang pada gilirannya mendorong perkembangan ilmu dan inovasi, sedangkan bagi peneliti maupun akademisi, repositori institusi dapat menjadi ajang promosi, diseminasi, dan meningkatkan dampak terhadap karya tulis yang dihasilkan. 
Tabel 9. Kriteria Jawaban Responden Terkait Banyaknya Peneliti yang Mengetahui Ketersediaan Repositori untuk Menyimpan Data dan Karya

\begin{tabular}{cccc}
\hline No & Katagori Jawaban & Frekuensi & Persentase \\
\hline 1 & Sangat setuju & 2 & 10,5 \\
2 & Setuju & 9 & 47,4 \\
3 & Kurang Setuju & 5 & 26,3 \\
4 & Tidak Setuju & 3 & 15,8 \\
5 & Sangat tidak Setuju & 0 & 0 \\
6 & Jumlah & 19 & 100 \\
\hline
\end{tabular}

Tabel 9. di atas menunjukkan bahwa peneliti di lembaga penelitian dengan status PUI telah mengetahui adanya ketersediaan repositori untuk menyimpan data dan karya ilmiah hasil penelitian.

Tabel 10. Kriteria Jawaban Responden Terkait Lembaga Penelitian yang Telah Melakukan Sosialisasi

\begin{tabular}{cccc}
\hline No & Katagori Jawaban & Frekuensi & Persentase \\
\hline 1 & Sangat setuju & 0 & 0 \\
2 & Setuju & 10 & 52,6 \\
3 & Kurang Setuju & 5 & 26,3 \\
4 & Tidak Setuju & 4 & 21,1 \\
5 & Sangat tidak Setuju & 0 & 0 \\
6 & Jumlah & 19 & 100 \\
\hline
\end{tabular}

Tabel 10. di atas menunjukkan bahwa sebagian besar lembaga yang disurvei telah melakukan sosialisasi tentang pemanfaatan repositori dengan hasil $52,6 \%$ setuju, kurang setuju $26,3 \%$ dan tidak setuju $21,1 \%$.

Tabel 11. Kriteria Jawaban Responden Terkait Lembaga Penelitian yang Memilki Regulasi atau Kebijakan Tentang Repositori

\begin{tabular}{cccc}
\hline No & Katagori Jawaban & Frekuensi & Persentase \\
\hline 1 & Sangat setuju & 0 & 0 \\
2 & Setuju & 13 & 68,6 \\
3 & Kurang Setuju & 3 & 15,7 \\
4 & Tidak Setuju & 3 & 15,7 \\
5 & Sangat tidak Setuju & 0 & 0 \\
6 & Jumlah & 19 & 100 \\
\hline
\end{tabular}

Tabel 11. di atas menunjukkan bahwa sebagian besar lembaga penelitian yang disurvei sudah memiliki regulasi atau kebijakan. Hal tersebut juga didukung dari hasil wawancara yang mengatakan bahwa regulasi atau kebijakan sebenarnya sudah dibuat, namun implementasi belum berjalan. Hal ini disebabkan karena kultur yang belum terbangun di kalangan peneliti untuk menyimpan data hasil penelitian. Menurut Rianto S. et al (2019) kebijakan repositori dikelompokan menjadi 3 bagian; pertama, yaitu data terbuka (open data) adalah data yang dapat digunakan secara bebas. Kedua, data moderasi adalah data yang dibatasi penggunaannya oleh pemilik data, dan Ketiga, data tertutup adalah data yang dapat diakses oleh subjek, pemilik data, dan instansi tempat bekerja. 
Tabel 12. Kriteria Jawaban Responden Terkait Manfaat Ketersediaan Repositori

\begin{tabular}{cccc}
\hline No & Katagori Jawaban & Frekuensi & Persentase \\
\hline 1 & Sangat setuju & 9 & 47,4 \\
2 & Setuju & 10 & 52,6 \\
3 & Kurang Setuju & 0 & 0 \\
4 & Tidak Setuju & 0 & 0 \\
5 & Sangat tidak Setuju & 0 & 0 \\
6 & Jumlah & 19 & 100 \\
\hline
\end{tabular}

Tabel 12. di atas menggambarkan seluruh responden menyatakan manfaat ketersediaan repositori adalah untuk menyimpan data dan karya ilmiah dalam satu tempat. Hal tersebut sesuai dengan pernyataan dari Sutejo (2014) yang mengatakan bahwa repositori institusi adalah arsip online untuk mengumpulkan, melestarikan, dan menyebarluaskan salinan digital karya ilmiah intelektual dari sebuah lembaga, khususnya lembaga penelitian.

Tabel 13. Kriteria Jawaban Responden Terkait Manfaat Repositori yang Dapat Mempercepat Publikasi Karya Ilmiah

\begin{tabular}{cccc}
\hline No & Katagori Jawaban & Frekuensi & Persentase \\
\hline 1 & Sangat setuju & 7 & 36,8 \\
2 & Setuju & 12 & 63,2 \\
3 & Kurang Setuju & 0 & 0 \\
4 & Tidak Setuju & 0 & 0 \\
5 & Sangat tidak Setuju & 0 & 0 \\
6 & Jumlah & 19 & 100 \\
\hline
\end{tabular}

Berkaitan dengan manfaat repositori yang dapat mempercepat publikasi karya ilmiah menunjukkan bahwa sebagian besar responden setuju dengan pernyataan tersebut. Hal tersebut dibuktikan dengan kriteria jawaban responden pada tabel 13. di atas. Hal tersebut sesuai dengan penelitian yang dilakukan oleh Asmad, C. C. Et al (2018).

Tabel 14. Ketersediaan Repositori Institusi Dapat Mempercepat Proses Publikasi Data Ilmiah

\begin{tabular}{cccc}
\hline No & Katagori Jawaban & Frekuensi & Persentase \\
\hline 1 & Sangat setuju & 6 & 31,6 \\
2 & Setuju & 12 & 63,2 \\
3 & Kurang Setuju & 1 & 5,3 \\
4 & Tidak Setuju & 0 & 0 \\
5 & Sangat tidak Setuju & 0 & 0 \\
6 & Jumlah & 19 & 100 \\
\hline
\end{tabular}

Tabel 15. Kriteria Jawaban Responden Terkait Manfaat Repositori untuk Menyebarkan Karya Ilmiah yang Tidak Dipublikasikan Di Jurnal

\begin{tabular}{cccc}
\hline No & Katagori Jawaban & Frekuensi & Persentase \\
\hline 1 & Sangat setuju & 6 & 31,6 \\
2 & Setuju & 11 & 57,9 \\
3 & Kurang Setuju & 2 & 10,5 \\
4 & Tidak Setuju & 0 & 0 \\
5 & Sangat tidak Setuju & 0 & 0 \\
6 & Jumlah & 19 & 100 \\
\hline
\end{tabular}


Tabel 16. Kriteria Jawaban Responden Terkait Manfaat Repositori Institusi Dapat Menghemat Biaya dan Peneliti Tidak Harus Mengelola Sendiri

\begin{tabular}{cccc}
\hline No & Katagori Jawaban & Frekuensi & Persentase \\
\hline 1 & Sangat setuju & 5 & 26,3 \\
2 & Setuju & 12 & 63,2 \\
3 & Kurang Setuju & 2 & 10,5 \\
4 & Tidak Setuju & 0 & 0 \\
5 & Sangat tidak Setuju & 0 & 0 \\
6 & Jumlah & 19 & 100 \\
\hline
\end{tabular}

Tabel 17. Kriteria Jawaban Responden Terkait Repositori Institusi Menyediakan Penyimpanan Data Ilmiah untuk Jangka Panjang

\begin{tabular}{cccc}
\hline No & Katagori Jawaban & Frekuensi & Persentase \\
\hline 1 & Sangat setuju & 5 & 26,3 \\
2 & Setuju & 12 & 63,2 \\
3 & Kurang Setuju & 2 & 10,5 \\
4 & Tidak Setuju & 0 & 0 \\
5 & Sangat tidak Setuju & 0 & 0 \\
6 & Jumlah & 19 & 100 \\
\hline
\end{tabular}

Tabel 18. Kriteria Jawaban Repositori Institusi Menyediakan Penyimpanan Karya Ilmiah untuk Jangka Panjang

\begin{tabular}{cccc}
\hline No & Katagori Jawaban & Frekuensi & Persentase \\
\hline 1 & Sangat setuju & 6 & 31,6 \\
2 & Setuju & 13 & 68,4 \\
3 & Kurang Setuju & 0 & 0 \\
4 & Tidak Setuju & 0 & 0 \\
5 & Sangat tidak Setuju & 0 & 0 \\
6 & Jumlah & 19 & 100 \\
\hline
\end{tabular}

Tabel 19. Kriteria Jawaban Repositori Institusi Dapat Memudahkan Orang untuk Menelusur atau Merujuk Data dan Karya Peneliti Lain

\begin{tabular}{cclc}
\hline No & Katagori Jawaban & Frekuensi & Persentase \\
\hline 1 & Sangat setuju & 7 & 36,8 \\
2 & Setuju & 11 & 57,9 \\
3 & Kurang Setuju & 1 & 5,3 \\
4 & Tidak Setuju & 0 & 0 \\
5 & Sangat tidak Setuju & 0 & 0 \\
6 & Jumlah & 19 & 100 \\
\hline
\end{tabular}

Tabel 20. Kriteria Jawaban Responden Terkait Repositori Dapat Memfasilitasi Kolaborasi Antar Disiplin Ilmu

\begin{tabular}{cccc}
\hline No & Katagori Jawaban & Frekuensi & Persentase \\
\hline 1 & Sangat setuju & 7 & 36,8 \\
2 & Setuju & 12 & 63,2 \\
3 & Kurang Setuju & 0 & 0 \\
\hline
\end{tabular}




\begin{tabular}{cccc}
\hline 4 & Tidak Setuju & 0 & 0 \\
5 & Sangat tidak Setuju & 0 & 0 \\
6 & Jumlah & 19 & 100 \\
\hline
\end{tabular}

Tabel 20. di atas menggambarkan bahwa ketersediaan repositori dapat memfasilitasi antar disiplin ilmu baik dalam pembelajaran maupun penelitian. Sebagaimana Harliansyah (2016) mengatakan bahwa repositori dapat menaikkan tingkat visibility suatu penelitian atau karya ilmiah karena masyarakat dunia dapat dengan mudah mengaksesnya baik secara langsung maupun melalui academic search engine seperti Google Scholar, BASE, CORE dan lain-lain. Beberapa penelitian mengungkapkan bahwa repositori mempunyai potensi yang cukup besar untuk meningkatkan global visibility.

Tabel 21. Kriteria Jawaban Responden Terkait Tampilan Web Repositori yang Lembaga Penelitian

\begin{tabular}{cccc}
\hline No & Katagori Jawaban & Frekuensi & Persentase \\
\hline 1 & Sangat setuju & 4 & 21,4 \\
2 & Setuju & 9 & 47,4 \\
3 & Kurang Setuju & 5 & 26,3 \\
4 & Tidak Setuju & 1 & 5,3 \\
5 & Sangat tidak Setuju & 0 & 0 \\
6 & Jumlah & 19 & 100 \\
\hline
\end{tabular}

Tabel 21. di atas menggambarkan bahwa faktor yang dapat mendorong penggunaan repositori lembaga adalah tampilan web repositori yang menarik. Hal tersebut didukung dengan hasil wawancara dengan pengelola repositori Pusat Unggulan Iptek Bioprospeksi Laut Pusat Penelitian Oseanografi LIPI menunjukkan bahwa tampilan web masih perlu disempurnakan baik terhadap konten maupun tampilan web meskipun tidak merasa kesulitan dalam mengakses informasi.

Tabel 22. Kriteria Jawaban Responden Terkait Repositori Institusi yang Mudah Diakses

\begin{tabular}{cccc}
\hline No & Katagori Jawaban & Frekuensi & Persentase \\
\hline 1 & Sangat setuju & 2 & 10,5 \\
2 & Setuju & 9 & 47,4 \\
3 & Kurang Setuju & 7 & 36,8 \\
4 & Tidak Setuju & 1 & 5,3 \\
5 & Sangat tidak Setuju & 0 & 0 \\
6 & Jumlah & 19 & 100 \\
\hline
\end{tabular}

Keberadaan repositori lembaga penelitian yang mudah diakses dapat mendorong penggunaan repositori tersebut untuk kepentingan penelitian maupun untuk berkolaborasi dengan peneliti lainnya. Berdasarkan hasil wawancara dengan pengelola repositori di Pusat Penelitian dan Pengembangan Hutan (P3H) menunjukkan bahwa lembaganya sudah memiliki repositori sejak tahun 2015. Sistem repositori ini sudah disiapkan untuk data mentah yang tercecer di berbagai tempat dan sekecil apapun data penelitian yang dimiliki akan dimasukkan ke dalam sistem repositori secara mandiri yang hanya dapat diakses oleh kalangan sendiri dan tidak dibuka untuk umum. 
Tabel 23. Kriteria Jawaban Responden Terkait Keberadaan Repositori yang Sudah Dilengkapi dengan Fasilitas untuk Penyimpanan dan Pencarian Data

\begin{tabular}{cccc}
\hline No & Katagori Jawaban & Frekuensi & Persentase \\
\hline 1 & Sangat setuju & 2 & 10,5 \\
2 & Setuju & 7 & 36,8 \\
3 & Kurang Setuju & 8 & 42,1 \\
4 & Tidak Setuju & 2 & 10,5 \\
5 & Sangat tidak Setuju & 0 & 0 \\
6 & Jumlah & 19 & 100 \\
\hline
\end{tabular}

Faktor pendorong lainnya yang dapat meningkatkan penggunaan repositori lembaga adalah adanya fasilitas untuk penyimpanan dan pencarian data. Dengan adanya kedua fasilitas tersebut peneliti dapat menyimpan datanya secara mandiri. Data penelitian yang telah tersimpan dapat dimanfaatkan dan digunakan kembali oleh peneliti itu sendiri mapun oleh peneliti lainnya. Hal tersebut didukung oleh pendapat Yaniasih (2015) bahwa pengembangan repositori institusi yang dikembangkan dapat mendukung swaarsip di lembaga penelitian. Konsep repositori di lembaga penelitian yang efektif untuk mencapai kualitas terbaik dengan kebijakan wajib deposit teks lengkap karya ilmiah dan kebijakan akses oleh semua masyarakat dengan pembatasan hanya pada beberapa karya tertentu. Kebijakan ini didukung dengan konsep web yang memiliki fasilitas deposit untuk swaarsip peneliti secara mudah, cepat dan tepat; fasilitas pencarian yang memudahkan pengguna mendapatkan informasi dengan tepat; serta fitur pendukung yang memberikan nilai tambah untuk meningkatkan kualitas peneliti, Repositori Institusi dan lembaga induk.

Tabel 24. Kriteria Jawaban Responden Terkait Kewajiban untuk Menyimpan Data dan Karya dalam Repositori

\begin{tabular}{cccc}
\hline No & Katagori Jawaban & Frekuensi & Persentase \\
\hline 1 & Sangat setuju & 2 & 10,5 \\
2 & Setuju & 7 & 36,8 \\
3 & Kurang Setuju & 8 & 42,1 \\
4 & Tidak Setuju & 2 & 10,5 \\
5 & Sangat tidak Setuju & 0 & 0 \\
6 & Jumlah & 19 & 100 \\
\hline
\end{tabular}

Tabel 25. di atas menunjukkan bahwa faktor yang menghambat penggunaan repositori adalah karena lembaga penelitian belum mewajibkan kepada para peneliti untuk menyimpan data penelitian. Dari hasil wawancara dengan pengelola repositori BBRP2KP, sebenarnya kebijakan atau aturan yang mengatur dan menekankan supaya peneliti menyimpan data penelitian di sistem repositori sudah dibuat di tingkat Eselon 2 namun belum disosialisasikan sehingga para peneliti belum mengetahui bahwa ada kewajiban untuk menyimpan data.

Tabel 25. Kriteria Jawaban Responden Terkait Evaluasi Perbaikan Sistem Repositori

\begin{tabular}{cccc}
\hline No & Katagori Jawaban & Frekuensi & Persentase \\
\hline 1 & Sangat setuju & 4 & 21,1 \\
2 & Setuju & 8 & 42,1 \\
3 & Kurang Setuju & 5 & 26,3 \\
4 & Tidak Setuju & 2 & 10,5 \\
5 & Sangat tidak Setuju & 0 & 0 \\
6 & Jumlah & 19 & 100 \\
\hline
\end{tabular}


Perbaikan sistem repositori yang dilakukan secara berkala dan selalau dievaluasi dapat menjadi faktor pendorong untuk peningkatan penggunaan repositori.

\section{KESIMPULAN}

Berdasarkan hasil dan pembahasan di atas dapat disimpulkan bahwa lembaga penelitian dengan status Pusat Unggulan Iptek sebagian besar sudah memiliki repositori. Ide mengembangkan repositori karena adanya kebutuhan untuk menyimpan data dan karya hasil penelitian dalam satu tempat. Repositori berfungsi sebagai penyedia tempat penyimpanan data dan karya ilmiah untuk jangka panjang dalam bentuk digital repository. Lembaga penelitian dapat menghemat biaya dan peneliti tidak harus mengelola sendiri data dan karyanya. Repositori dapat memudahkan orang untuk menelusur atau merujuk data dan karya penelitian lain. Kertersediaan repositori institusi juga dapat memfasilitasi antar disiplin ilmu baik dalam pembelajaran maupun penelitian. Faktor yang mendorong penggunaan repositori adalah tampilan web repositori menarik, repositori dilengkapi dengan fasilitas penyimpanan dan pencarian data serta mudah diakses. Sedangkan faktor yang menghambat penggunaan repositori adalah lembaga penelitian belum mewajibkan peneliti untuk menyimpan data penelitian dalam repositori. Faktor lain yang menghambat penggunaan repositori adalah perilaku peneliti yang tidak melakukan backup data.

Hasil penelitian diharapkan dapat digunakan sebagai masukan kepada pimpinan lembaga penelitian khususnya lembaga penelitian dan pengembangan dengan status PUI dalam mengembangkan repositori Ilmiah. Adanya repositori ilmiah yang dikembangkan oleh lembaga penelitian dan pengembangan dengan status PUI dapat diikuti pengembangannya oleh lembaga lain. Dengan demikian karya ilmiah yang dihasilkan oleh lembaga dapat tersimpan dengan baik dan dapat ditemukan kembali untuk pengembangan ilmu pengetahuan di masa yang akan datang. Ketersedian repositori di lembaga penelitian juga dapat menghemat biaya dan peneliti tidak harus mengelola sendiri data dan karyanya.

\section{DAFTAR PUSTAKA}

Asmad, C. C., Mathar, T., Akbar, A. K., Arifin, N., Hijrana., Haruddin., Irmawati., Irawati., \& Satriani. (2018). Tren perkembangan open access institutional repository pada perguruan tinggi di Indonesia . Khizanah al-Hikmah : Jurnal Ilmu Perpustakaan, Informasi, dan Kearsipan. 6(2), 168-180.

Abrizah, A., Noorhidawati, A., \& Kiran, K. (2010). Global visibility of Asian universities' Open Access institutional repositories. Malaysian Journal of Library \& Information Science, 15(3): 53-73.

Kumar, N., Ashok. (2009). Institutional Repositories in India. In National Seminar on Strategic Information Management in the Digital Era, Tamil Nadu (India), 26-27 March 2009. [Conference paper], diakses dari http://hdl.handle.net/10760/17511; pada 20 Februari 2019

Directory of Institutional Repositories in Malaysia (2019). diakses dari: (https://umlib.um.edu.my/scontents.asp?tid=31\&cid=144\&p=1\&vs=en), Tanggal 26 Februari 2019.

Ernaningsih, D. N. (2017). Kebijakan Akses Institutional Repository: Studi Kasus di Perpustakaan Universitas Negeri Malang. Record and Library Journal Volume 3, Nomor 1, Januari - Juni 2017

Harliansyah, F. (2016). Institutional Repository Sebagai Sarana Komunikasi Ilmiah yang Sustainable dan Reliable. Pustakaloka Vol 8, No 1 (2016

Jain, S. J., \& S, Anurag. (2018). Academic institutional repositories in India : Global visibility for institution's scholarly communication.Diakses dari ResearchGate dengan alamat ; http: www.researchgate.net/publication/279663182. ; tanggal 25 Februari 2019. 
Kumar Roy, B., Mukhopadhyay, P., \& Chandra Biswas, S. (2012). "An Analytical Study of Institutional Digital Repositories in India". Library Philosophy and Practice (e-journal). 692. http://digitalcommons.unl.edu/libphilprac/692, diaskes 25 Februari 2019.

Prayesti, M., Iswanda, F., Satibi., Rizki, A., Soraya, D., Anggraini., \& Novi. (2017) Faktor Pengembangan Repositori Institusi Di Pemerintah Daerah: Studi Kasus pengembangan Repositori Institusi Di Kabupaten Pamekasan. Seminar Nasional \& Call for Papers Prodi Ilmu Perpustakaan Universitas Muhamadiyah Malang 2017. Rekonstruksi Peran Perpustakaan dan Pustakawan Di Era Informasi” Malang, 30 Agustus 2017 - Isbn : 978602-60077-1-1

Rifqi, A. N. (2018). Implementasi Sistem Institutional Repository Hasil Karya Ilmiah Sivitas Akademika Politeknik Negeri Malang (Studi Pengembangan Sistem Menggunakan System Development Life Cyle: SDLC. JURNAL PUBLIS 2(1): 2018.

Sutedjo, M. (2014). Pengelolaan Repositori Perguruan Tinggi dan Pengembangan Repositori Karya seni. Makalah disampaikan pada "Seminar Nasional Digital Local Content: Strategi Membangun Repository Karya Seni," di GKU FSR ISI Yogyakarta, 21 Mei 2014.

Siaran Pers Ristekdikti Siaran Pers, Nomor : 343/SP/HM/BKKP/XII/2018 (2018). Diakses dari: https://ristekdikti.go.id/siaran-pers/pemerintah-berikan-penghargaan-ke-101lembaga-penelitian-termasuk-lembaga-penelitian-sosial-danperusahaan/\#0VhDlto5AhwM36pi.99 . Diakses tanggal 25 Februari 2019.

Sugiono. (2008) Metode Penelitian Pendidikan: Pendekatan Kuantitatif, Kualitatif, dan R \& D. Bandung: Alfabeta

Sukmadinata, N. S. (2006). Metode Penelitian Pendidikan. Bandung: PT Remaja Rosdakarya. Ulum, A. (2015). Evaluasi website repositori institusi universitas Surabaya. Pustakaloka. 7(1).

Yaniasih. (2015). Analisis dan Desain Konseptual Repositori Institusi yang Mendukung Swaarsip Peneliti di Lembaga Ilmu Pengetahuan Indonesia. Sekolah Pascasarjana Institut Pertanian Bogor Bogor. 